\title{
Identification of acetic acid bacteria by RFLP of PCR-amplified 16S rDNA and 16S-23S rDNA intergenic spacer
}

\author{
Alfonso Ruiz, Montse Poblet, Albert Mas and José M. Guillamón
}

Unitat d'Enologia, Centre de Referència en Tecnologia d'Aliments (CeRTA), Departament de Bioquímica i Biotecnologia, Facultat d'Enologia, Universitat Rovira i Virgili, Ramón y Cajal 70, 43005 Tarragona, Spain

\author{
Author for correspondence: José M. Guillamón. Tel: + 34 977250358. Fax: + 34977250347. \\ e-mail: jmgn@astor.urv.es
}

DNA corresponding to 16S rDNA and the 16S-23S rDNA intergenic spacer (ITS) from 22 reference strains of acetic acid bacteria, representing the diversity of the family Acetobacteraceae, and 24 indigenous acetic acid bacteria isolated from wine fermentations were analysed by PCR-RFLP. Frateuria aurantia LMG $1^{1558}{ }^{\top}$ and Escherichia coli ATCC $11775^{\top}$ were included as outgroups. PCRamplified products of about $1450 \mathrm{bp}$ were obtained from the 16S rDNA of all the strains and products of between 675 and 800 bp were obtained from the 16S-23S rDNA ITS. PCR products were digested with 4-base-cutting restriction enzymes in order to evaluate the degree of polymorphism existing among these strains. Of the enzymes tested, Taql and Rsal were the most discriminatory and showed no intraspecific variations in the restriction patterns. Restriction analysis of the 16S rDNA with these enzymes is proposed as a rapid and reliable method to identify acetic acid bacteria at the level of genus and species (or related species group) and its applicability to identification of indigenous acetic acid bacteria was demonstrated. The same degree of distinction as that for the 16S rDNA analysis was obtained within reference strains of acetic acid bacteria by PCR-RFLP of the 16S-23S rDNA ITS. However, 16S-23S rDNA ITS restriction patterns of strains isolated from wine did not match those of any of the reference strains. Thus, PCR-RFLP of the 16S-23S rDNA ITS is not a useful method to identify isolates of acetic acid bacteria at the species level, although it may be an adequate method to detect intraspecific differentiation.

Keywords: acetic acid bacteria, identification, PCR-RFLP, 16S rDNA, rDNA $16 \mathrm{~S}-23 \mathrm{~S}$ ITS

\section{INTRODUCTION}

Acetic acid bacteria are Gram-negative or Gramvariable, ellipsoidal to rod-shaped cells that have an obligately aerobic metabolism with oxygen as the terminal electron acceptor. They are classified in the family Acetobacteraceae as a branch of the acidophilic bacteria in the $\alpha$-subdivision of the Proteobacteria (De Ley et al., 1984; Sievers et al., 1994). Members of the family are recognized by their unique ability to oxidize ethanol to acetic acid in neutral and acidic ( $\mathrm{pH} 4 \cdot 5)$ media. They include bacteria with relevant industrial applications in the production of vinegar (Gluconacetobacter europaeus), gluconate and sorbose (Glu-

Abbreviation: ITS, internal transcribed spacer. conobacter oxydans) and paper from cellulose (Gluconacetobacter xylinus) due to their abilities to oxidize alcohols and sugars and to synthesize bacterial cellulose.

Genotypic relationships among acetic acid bacteria have been studied by DNA-DNA hybridization (Entani et al., 1985; Mason \& Claus, 1989; Micales et al., 1985; Sievers et al., 1992; Urakami et al., 1989; Yamada et al., 1984), DNA-RNA hybridization (Gillis \& De Ley, 1980) and 5S and 16S rDNA sequence analysis (Bulygina et al., 1992; Sievers et al., 1994; Yamada et al., 1997). The most recent approaches to classification within the family Acetobacteraceae (Gillis et al., 1989; Mason \& Claus, 1989; Urakami et al., 1989; Yamada \& Kondo, 1984; Yamada et al., 1997) reveal the existence of four well- 
Table 1. Reference strains used in this study

Sources of strains are abbreviated as: LMG, Laboratorium voor Microbiologie Universiteit Gent, Belgium; CECT, Colección Española de Cultivos Tipo, Valencia, Spain; DSM, Deutsche Sammlung von Mikroorganismen und Zellkulturen GmbH, Braunschweig, Germany; ATCC, American Type Culture Collection, Manassas, VA, USA. NK, Not known.

\begin{tabular}{|c|c|c|c|c|}
\hline Species & Strain & Other designations & Origin & Accession no. \\
\hline Gluconobacter oxydans & LMG $1408^{\mathrm{T} *}$ & DSM $3505^{\mathrm{T}}$ & Beer & X73820 \\
\hline Gluconobacter oxydans & CECT $360^{\mathrm{T} *}$ & - & Beer & X73820 \\
\hline Gluconobacter oxydans & LMG 1484 & - & Amstel beer & - \\
\hline Gluconobacter oxydans & LMG 1414 & - & Grapes & - \\
\hline Gluconobacter frateurii & LMG $1365^{\mathrm{T}}$ & DSM $7146^{\mathrm{T}}$ & Fragaria ananassa & - \\
\hline Gluconobacter asaii & LMG $1390^{\mathrm{T}}$ & DSM $7148^{\mathrm{T}}$ & Rheum rhabarbarum, flower & - \\
\hline Acidomonas methanolica & LMG $1668^{\mathrm{T}}$ & DSM $5432^{\mathrm{T}}$ & $\begin{array}{l}\text { Fermentation of ethanol with } \\
\text { Candida sp. (non-sterile) }\end{array}$ & - \\
\hline Acetobacter aceti & LMG $1261^{\mathrm{T}} \dagger$ & DSM $3508^{T}$ & $\begin{array}{l}\text { Beech-wood shavings } \\
\text { from a vinegar plant }\end{array}$ & X74066 \\
\hline Acetobacter aceti & CECT $298^{\mathrm{T}} \uparrow$ & DSM $3508^{T}$ & $\begin{array}{l}\text { Beech-wood shavings } \\
\text { from a vinegar plant }\end{array}$ & - \\
\hline Acetobacter aceti & LMG 1505 & - & Quick vinegar & - \\
\hline Acetobacter aceti & LMG 1372 & - & $\begin{array}{l}\text { Nakano Rice-Vinegar } \\
\text { Producing Company }\end{array}$ & - \\
\hline Acetobacter pasteurianus & LMG $1262^{\mathrm{T}}$ & DSM $3505^{\mathrm{T}}$ & Beer & - \\
\hline Acetobacter pasteurianus & LMG 1553 & - & Spoiled beer & - \\
\hline Acetobacter pasteurianus & LMG 1282 & - & Beer & - \\
\hline Gluconacetobacter hansenii & LMG $1527^{\mathrm{T}}$ & DSM $5602^{\mathrm{T}}$ & Vinegar & X75620 \\
\hline Gluconacetobacter hansenii & LMG 1511 & - & NK & - \\
\hline Gluconacetobacter liquefaciens & LMG $1381^{\mathrm{T}}$ & DSM $5603^{T}$ & Dried fruit & - \\
\hline Gluconacetobacter liquefaciens & LMG 1347 & - & Fruit & - \\
\hline Gluconacetobacter xylinus & LMG $1515^{\mathrm{T}}$ & DSM $5615^{\mathrm{T}}$ & Mountain ash berries & X75619, X89812 \\
\hline Gluconacetobacter xylinus & LMG 1518 & - & NK & - \\
\hline Gluconacetobacter diazotrophicus & DSM $5601^{\mathrm{T}}$ & - & Sugar-cane roots & - \\
\hline Gluconacetobacter europaeus & DSM $6160^{\mathrm{T}}$ & - & $\mathrm{NK}$ & Z21936, X89771 \\
\hline Frateuria aurantia & LMG $1558^{\mathrm{T}}$ & DSM $6220^{\mathrm{T}}$ & Lilium auratum & - \\
\hline Escherichia coli & ATCC $11775^{\mathrm{T}}$ & - & NK & - \\
\hline
\end{tabular}

* Synonymous strains.

$\uparrow$ Synonymous strains.

defined genera: Acetobacter $\left(\right.$ Acetobacter aceti $^{\mathrm{T}}$ and Acetobacter pasteurianus), Acidomonas (Acidomonas methanolica ${ }^{\mathrm{T}}$ ), Gluconacetobacter (Gluconacetobacter liquefaciens ${ }^{\mathrm{T}}$, Gluconacetobacter hansenii, Gluconacetobacter xylinus, Gluconacetobacter europaeus and Gluconacetobacter diazotrophicus) and Gluconobacter

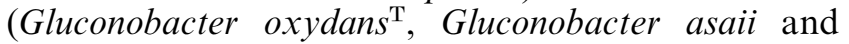
Gluconobacter frateurii). In addition, the new species Acetobacter oboediens, Acetobacter pomorum, Acetobacter intermedius and Gluconacetobacter sacchari have been reported recently (Sokollek et al., 1998; Boesch et al., 1998; Franke et al., 1999).

RFLP analysis of PCR-amplified 16S rDNA is an appropriate technique for the differentiation and characterization of micro-organisms on the basis of their phylogenetic relationships (Carlotti \& Funke, 1994). In eubacterial DNA, the rRNA genetic loci include $16 \mathrm{~S}, 23 \mathrm{~S}$ and $5 \mathrm{~S}$ rRNA genes, which are separated by internally transcribed spacer (ITS) regions. It is known that DNA sequences in the
$16 \mathrm{~S}-23 \mathrm{~S}$ ITS exhibit a great deal of sequence and length variation (Barry et al., 1991; Navarro et al., 1992) and conserved sequences with functional roles (tRNA genes, antitermination sequences) are also found within the ITS (Sievers et al., 1996). It has been shown that PCR-RFLP analysis of the ITS is an appropriate method for differentiating species (Jensen et al., 1993) and even strains of prokaryotes (Navarro et al., 1992).

The objective of the present study was to evaluate the usefulness of PCR-RFLP analysis of the 16S rDNA and $16 \mathrm{~S}-23 \mathrm{~S}$ intergenic spacer in order to characterize acetic acid bacteria as well as to identify natural isolates belonging to this group.

\section{METHODS}

Strains, media and growth conditions. Reference strains used in this study are listed in Table 1 . They were grown on solid GYC medium (5\% D-glucose, $1 \%$ yeast extract, $0.5 \%$ 
$\mathrm{CaCO}_{3}$ and $2 \%$ agar, w/v). Twenty-four indigenous strains were isolated selectively by plating wine samples on the same medium at $\mathrm{pH} 4 \cdot 5$, without $\mathrm{CaCO}_{3}$ and supplemented with pimaricin $\left(100 \mathrm{mg}^{-1}\right)$ to inhibit the growth of yeasts and moulds and penicillin $\left(3 \mathrm{U} \mathrm{ml}^{-1}\right)$ to inhibit lactic acid bacteria. Both antibiotics were added to the culture medium from stock solutions after sterilizing the medium. Plates were incubated at $28^{\circ} \mathrm{C}$ for $2-4 \mathrm{~d}$ under aerobic conditions.

Biochemical identification tests. Some biochemical identification tests were performed in order to validate the data obtained by PCR-RFLP. The following principal characteristics were used for differentiation: (i) the ability or inability to degrade lactate distinguished Acetobacter from Gluconobacter; (ii) within Acetobacter, the ability or inability to oxidize glycerol distinguished Acetobacter aceti from Acetobacter pasteurianus. Gluconacetobacter hansenii was distinguished by its inability to grow with ethanol as carbon source. All the tests were performed as described previously (Buchanan \& Gibbons, 1984; Drysdale \& Fleet, 1985; Joyeux et al., 1984).

DNA extraction. For each strain studied, a single colony was picked from a fresh culture on GYC medium and resuspended in $50 \mu \mathrm{l}$ sterile deionized water (MilliQ) in a $0.5 \mathrm{ml}$ tube. The mixture was vortexed for $15 \mathrm{~s}$ and then incubated at $95^{\circ} \mathrm{C}$ for $15 \mathrm{~min}$. After centrifugation $(5000 \mathrm{~g}$, $4{ }^{\circ} \mathrm{C}, 5 \mathrm{~min}$ ), the supernatant containing the released DNA was used as the source of target DNA for PCR amplification.

Oligonucleotide primers. PCR primers used to amplify the 16S-23S rDNA spacer region were selected on the basis of the sequences of $16 \mathrm{~S}$ ( $3^{\prime}$-end; its1, 5'-ACCTGCGGCTGGATCACCTCC-3') and 23S (5'-end; its2, 5'-CCGAATGCCCTTATCGCGCTC-3') rRNA genes conserved among acetic acid bacteria. Primers for the PCR amplification of $16 \mathrm{~S}$ rDNA were selected from conserved regions of the $5^{\prime}-$ end (16Sd, 5'-GCTGGCGGCATGCTTAACACAT-3') and the $3^{\prime}$-end (16Sr, 5'-GGAGGTGATCCAGCCGCAGGT$\left.3^{\prime}\right)$ of the $16 \mathrm{~S}$ rDNA. Primers its 1 and $16 \mathrm{Sr}$ were complementary.

All multiple sequence alignments were performed with CLUSTAL W (Higgins \& Sharp, 1988). The design of the primers was carried out by following criteria described previously (Bej et al., 1991).

PCR amplification. PCR amplification was carried out in $50 \mu \mathrm{l}$ samples consisting of $5 \mu \mathrm{l}$ bacterial extract and $45 \mu \mathrm{l}$ amplification mixture, which contained 15 pmol of each primer, $200 \mu \mathrm{M}$ of each of the four dNTPs, $5 \mu \mathrm{l} 10 \times$ amplification buffer (ECOGEN; ARK Scientific), $3 \mathrm{mM} \mathrm{MgCl}{ }_{2}$ and $2.5 \mathrm{U}$ Taq DNA polymerase (ECOGEN; ARK Scientific).

The reaction was performed in a GeneAmp PCR System 2400 (Perkin-Elmer). For the amplification of the 16S-23S intergenic spacer, the samples were incubated for $5 \mathrm{~min}$ at $94{ }^{\circ} \mathrm{C}$ to denature the target DNA and then cycled 35 times at $94{ }^{\circ} \mathrm{C}$ for $30 \mathrm{~s}, 65^{\circ} \mathrm{C}$ for $30 \mathrm{~s}$ and $72^{\circ} \mathrm{C}$ for $1 \mathrm{~min}$. The samples were then incubated for $7 \mathrm{~min}$ at $72{ }^{\circ} \mathrm{C}$ for a final extension and were maintained at $4{ }^{\circ} \mathrm{C}$ until tested. For amplification of the $16 \mathrm{~S}$ rDNA, samples were incubated for $5 \mathrm{~min}$ at $94{ }^{\circ} \mathrm{C}$ and then cycled 35 times at $94^{\circ} \mathrm{C}$ for $1 \mathrm{~min}$, $58^{\circ} \mathrm{C}$ for $1 \mathrm{~min}$ and $72{ }^{\circ} \mathrm{C}$ for $2 \mathrm{~min}$. The samples were then incubated for $10 \mathrm{~min}$ at $72^{\circ} \mathrm{C}$ for a final extension and maintained at $4{ }^{\circ} \mathrm{C}$ until tested.

Restriction of amplified DNA. Five microlitres of each PCRamplified product was digested with restriction endo- nucleases as recommended by the manufacturer. Restriction enzymes were obtained from Boehringer Mannheim.

Gel electrophoresis. Amplified DNA was detected by electrophoresis on a $0.8 \%(\mathrm{w} / \mathrm{v})$ agarose gel in $1 \times \mathrm{TBE}$ buffer, while the restriction fragments were separated on a $3 \%$ $(\mathrm{w} / \mathrm{v})$ agarose gel. Short restriction fragments $(<400 \mathrm{bp})$ were resolved better on a $5 \%(\mathrm{w} / \mathrm{v})$ agarose gel. The gels were stained with ethidium bromide and photographed. The lengths of both amplified products and restriction fragments were estimated by comparison against a $100 \mathrm{bp}$ DNA ladder (Gibco-BRL).

\section{RESULTS}

\section{PCR-RFLP of the 16S rDNA: characterization of reference strains}

PCR-amplified products corresponding to the $16 \mathrm{~S}$ rRNA gene were obtained specifically from all strains. The PCR products contained approximately $1450 \mathrm{bp}$ (results not shown), while the expected length was 1458 bp. Co-migration of amplified rDNA from all strains indicated an identical size.

Eight 4-base restriction endonucleases ( $T a q \mathrm{I}, C f o \mathrm{I}$, HaeIII, AluI, HinfI, MboI, MspI and RsaI) were tested and cut the amplified 16S rDNA. RFLPs were observed with all the enzymes (Fig. 1) and different

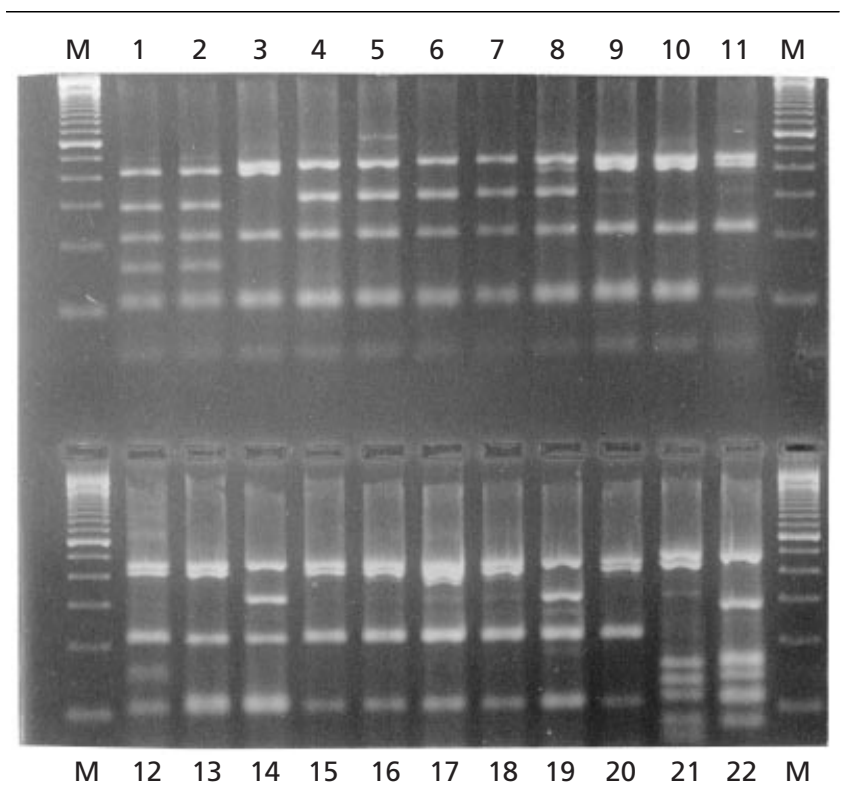

Fig. 1. Mspl restriction patterns of $P C R$-amplified 16S rDNA. Lanes: M, 100 bp DNA ladder (Gibco-BRL); 1-3, Gluconobacter oxydans LMG 1408' ${ }^{\top}$ LMG 1484 and LMG 1414; 4, Gluconobacter frateurii LMG $1365^{\top}$; 5, Gluconobacter asaii LMG $1390^{\top}$; 6-8, Acetobacter aceti LMG 1261 ${ }^{\top}$, LMG 1505 and LMG 1372; 9-10, Acetobacter pasteurianus LMG $1262^{\top}$ and LMG 1553; 11-12, Gluconacetobacter liquefaciens LMG $1381^{\top}$ and LMG 1347; 13-14, Gluconacetobacter hansenii LMG $1527^{\top}$ and LMG 1511; 15-16, Gluconacetobacter xylinum LMG $1515^{\top}$ and LMG 1518; 17, Acetobacter pasteurianus LMG 1282; 18, Gluconacetobacter europaeus DSM 6160'; 19, Gluconacetobacter diazotrophicus DSM 5601 ${ }^{\top} ; 20$, Acidomonas methanolica LMG $1668^{\top} ; 21$, F. aurantia LMG $1558^{\top} ; 22$, E. coli ATCC $11775^{\top}$. 
Table 2. Sizes of PCR-RFLP fragments obtained from the $16 \mathrm{~S}$ rDNA of acetic acid bacteria

Genera are abbreviated as: Ab., Acetobacter; Ac., Acidomonas; Ga., Gluconacetobacter; Gb., Gluconobacter.

\begin{tabular}{|c|c|c|c|c|}
\hline Strain & TaqI & RsaI & $A l u \mathbf{I}$ & MspI \\
\hline Gb. oxydans $\mathrm{LMG} 1408^{\mathrm{T}}$ & $350,190,175,160,120,120,110$ & $400,400,400,150,90$ & $550,290,210,190,125$ & $425,300,225,160,125,125$ \\
\hline Gb. oxydans CECT $360^{\mathrm{T}}$ & $350,190,175,160,120,120,110$ & $400,400,400,150,90$ & $550,290,210,190,125$ & $425,300,225,160,125,125$ \\
\hline Gb. oxydans LMG 1484 & $350,190,175,160,120,120,110$ & $400,400,400,150,90$ & $550,290,210,190,125$ & $425,300,225,160,125,125$ \\
\hline Gb. oxydans LMG 1414 & $350,190,175,160,120,120,110$ & $400,400,400,150,90$ & $550,290,210,190,125$ & $450,425,225,125,125$ \\
\hline Gb. frateurii $\mathrm{LMG} 1365^{\mathrm{T}}$ & $350,190,175,160,120,120,110$ & $400,400,300,150,130$ & $550,290,210,190,125$ & $450,310,225,125,125$ \\
\hline Gb. asaii LMG $1390^{\mathrm{T}}$ & $350,190,175,160,120,120,110$ & $400,400,300,150,130$ & $550,290,210,190,125$ & $450,310,225,125,125$ \\
\hline Ab. aceti $\mathrm{LMG} 1261^{\mathrm{T}}$ & $850,350,210$ & $500,400,300,150,125$ & $310,290,240,210,190,125$ & $450,310,225,125,125$ \\
\hline Ab. aceti CECT $298^{\mathrm{T}}$ & $850,350,210$ & $500,400,300,150,125$ & $310,290,240,210,190,125$ & $450,310,225,125,125$ \\
\hline Ab. aceti LMG 1505 & $850,350,210$ & $500,400,300,150,125$ & $310,290,240,210,190,125$ & $450,310,225,125,125$ \\
\hline Ab. aceti LMG 1372 & $850,350,210$ & $500,400,300,150,125$ & $310,290,240,210,190,125$ & $450,310,225,125,125$ \\
\hline Ga. hansenii LMG 1511* & $850,350,210$ & $500,400,300,150,125$ & $310,290,240,210,190,125$ & $450,310,225,125,125$ \\
\hline Ab. pasteurianus LMG $1262^{\mathrm{T}}$ & $500,350,330,210$ & $500,400,300,150,125$ & $450,310,290,190,190$ & $450,425,225,125,125$ \\
\hline Ab. pasteurianus LMG 1553 & $500,350,330,210$ & $500,400,300,150,125$ & $450,290,190,190,190,140$ & $450,425,225,125,125$ \\
\hline Ga. hansenii LMG $1527^{\mathrm{T}}$ & $650,350,210,175$ & $500,400,400,150$ & $790,480,125$ & $450,425,225,125,125$ \\
\hline Ga. liquefaciens $\mathrm{LMG} 1381^{\mathrm{T}}$ & $500,350,210,175,160$ & $500,400,400,150$ & $790,275,210,125$ & $450,425,225,225,125$ \\
\hline Ga. liquefaciens LMG 1347 & $500,350,210,175,160$ & $500,400,400,150$ & $790,275,210,125$ & $450,425,225,225,125$ \\
\hline Ga. xylinus $\mathrm{LMG} 1515^{\mathrm{T}}$ & $500,350,210,175,160$ & $500,400,400,150$ & $790,275,210,125$ & $450,425,225,225,125$ \\
\hline Ga. xylinus LMG 1518 & $500,350,210,175,160$ & $500,400,400,150$ & $790,275,210,125$ & $450,425,225,225,125$ \\
\hline Ab. pasteurianus $\mathrm{LMG} 1282 \dagger$ & $500,350,210,175,160$ & $500,400,400,150$ & $790,275,210,125$ & $450,425,225,225,125$ \\
\hline Ga. europaeus DSM $6160^{\mathrm{T}}$ & $500,350,210,175,160$ & $500,400,400,150$ & $790,275,210,125$ & $450,425,225,225,125$ \\
\hline Ga. diazotrophicus DSM $5601^{\mathrm{T}}$ & $500,350,210,175,160$ & $500,400,250,150,150$ & $790,275,210,125$ & $450,310,225,225,125,125$ \\
\hline Ac. methanolica LMG $1668^{\mathrm{T}}$ & $450,190,175,160,120,110$ & $500,400,400,150$ & $550,275,225,210,190$ & $450,425,225,225,125$ \\
\hline F. aurantia $\mathrm{LMG} 1558^{\mathrm{T}}$ & $600,350,210,175,125$ & $450,400,350,150$ & $350,300,225,210,175,125$ & $450,425,175,140,125,90$ \\
\hline E. coli & $750,350,210$ & $500,450,400,150$ & $350,350,225,210,100$ & $450,310,175,175,150,125,125,90$ \\
\hline
\end{tabular}

* Reclassified in this study as Acetobacter aceti.

$\dagger$ Reclassified in this study as Gluconacetobacter liquefaciens/Gluconacetobacter xylinus/Gluconacetobacter europaeus.

information was obtained with each one. As expected, the eight enzymes distinguished the acetic acid bacteria from the outgroups. Of all the enzymes tested, TaqI and $R s a \mathrm{I}$ were chosen for the identification. They distinguished the largest number of species of acetic acid bacteria without intraspecific variations, as seen in Table 2 in comparison with other restriction enzymes ( $A l u \mathrm{I}$ and $M s p \mathrm{I})$.

It is noteworthy that strain LMG 1282, classified as Acetobacter pasteurianus, did not give the same patterns as the type strain, LMG $1262^{\mathrm{T}}$. This strain grouped with strains of Gluconacetobacter liquefaciens, Gluconacetobacter xylinus and Gluconacetobacter europaeus with all the enzymes tested. In the same way, patterns for Gluconacetobacter hansenii LMG 1511 did not match those of Gluconacetobacter hansenii LMG $1527^{\mathrm{T}}$. The former strain showed the same restriction patterns as strains of Acetobacter aceti.

\section{PCR-RFLP of the 16S-23S rDNA ITS: characterization of reference strains}

Specific amplification of the intergenic sequence spanning the $16 \mathrm{~S}$ and $23 \mathrm{~S}$ rDNAs was achieved by using primers its1 and its2, with the exception of Gluconobacter asaii LMG $1390^{\mathrm{T}}$, Frateuria aurantia LMG $1558^{\mathrm{T}}$ and Escherichia coli ATCC $11775^{\mathrm{T}}$. As primer $16 \mathrm{Sr}$ was effective in amplifying the $16 \mathrm{~S}$ rDNA of these strains and primer its 1 is complementary to primer $16 \mathrm{Sr}$, the lack of amplification of the ITS sequence of these strains is probably due to failure of primer its 2 to anneal.
Conservation of the length of the 16S-23S rDNA ITS was observed at the species level, but this length varied from 675 to $800 \mathrm{bp}$ among some species. Digestion with the eight restriction endonucleases yielded practically the same degree of species differentiation as in the $16 \mathrm{~S}$ experiment (Table 3 ).

Strain LMG 1511, formerly classified as Gluconacetobacter hansenii, yielded a different pattern from that of Gluconacetobacter hansenii $\mathrm{LMG} 1527^{\mathrm{T}}$ in all cases, but, in contrast to the $16 \mathrm{~S}$ experiment, also showed restriction patterns that were different from those of the Acetobacter aceti strains. Acetobacter pasteurianus LMG 1282 again showed patterns the same as those of the Gluconacetobacter liquefaciens/Gluconacetobacter xylinus/Gluconacetobacter europaeus group.

\section{Identification of indigenous acetic acid bacteria}

Twenty-four colonies isolated from wine were tested for their 16S rDNA restriction patterns with TaqI and $R s a \mathrm{I}$. The patterns obtained with these endonucleases were the same as those of some reference strains, thus allowing the identification of the bacteria at the species level. Three strains were identified as Acetobacter aceti, one strain as Gluconacetobacter hansenii and 17 strains as Gluconobacter oxydans.

The length of the 16S-23S rDNA ITS was not conserved at the species level in the indigenous isolates, in contrast with the results obtained with the reference strains. Amplified ITS products were digested with $C f o \mathrm{I}$ and HaeIII. These enzymes were chosen ran- 
Table 3. Sizes of the amplified 16S-23S rDNA ITS and restriction fragments obtained from acetic acid bacteria

Genera are abbreviated as: Ab., Acetobacter; Ac., Acidomonas; Ga., Gluconacetobacter; Gb., Gluconobacter.

\begin{tabular}{|c|c|c|c|c|c|}
\hline Strain & ITS (bp) & TaqI & RsaI & AluI & MspI \\
\hline Gb. oxydans LMG $1408^{\mathrm{T}}$ & 700 & 410,290 & 700 & $190,190,175,110$ & $350,210,140$ \\
\hline Gb. oxydans CECT $360^{\mathrm{T}}$ & 700 & 410,290 & 700 & $190,190,175,110$ & $350,210,140$ \\
\hline Gb. oxydans LMG 1484 & 700 & 410,290 & 700 & $190,190,175,110$ & $350,210,140$ \\
\hline Gb. oxydans LMG 1414 & 700 & 410,290 & 700 & $350,110,110$ & $350,210,140$ \\
\hline Gb. frateurii $\mathrm{LMG} 1365^{\mathrm{T}}$ & 700 & 410,290 & 500,200 & $190,190,175,110$ & 550,150 \\
\hline Ab. aceti $\mathrm{LMG} 1261^{\mathrm{T}}$ & 750 & 375,325 & 750 & $290,130,110,90$ & 750 \\
\hline Ab. aceti CECT $298^{\mathrm{T}}$ & 750 & 375,325 & 750 & $290,130,110,90$ & 750 \\
\hline Ab. aceti $\mathrm{LMG} 1505$ & 750 & 375,325 & 750 & $290,130,110,90$ & 750 \\
\hline Ab. aceti $\mathrm{LMG} 1372$ & 750 & 375,325 & 750 & $290,130,110,90$ & 750 \\
\hline Ga. hansenii LMG 1511* & 800 & 405,395 & 800 & $325,190,110,90$ & 450,350 \\
\hline Ab. pasteurianus LMG $1262^{\mathrm{T}}$ & 750 & 375,325 & 750 & $290,130,110,90$ & 440,310 \\
\hline Ab. pasteurianus LMG 1553 & 750 & 375,375 & 650,100 & $290,130,110,90$ & 440,310 \\
\hline Ga. hansenii $\mathrm{LMG} 1527^{\mathrm{T}}$ & 775 & $425,190,160$ & 775 & $475,130,90$ & $450,160,100$ \\
\hline Ga. liquefaciens LMG $1381^{\mathrm{T}}$ & 725 & 390,375 & 425,300 & $425,210,110$ & $550,125,90$ \\
\hline Ga. liquefaciens LMG 1347 & 725 & 390,375 & 425,300 & $425,210,110$ & $550,125,90$ \\
\hline Ga. xylinus $\mathrm{LMG} 1515^{\mathrm{T}}$ & 725 & 390,375 & 425,300 & $425,210,110$ & $550,125,90$ \\
\hline Ga. xylinus LMG 1518 & 725 & 390,375 & 425,300 & $425,210,110$ & $550,125,90$ \\
\hline Ab. pasteurianus $\mathrm{LMG} 1282 \dagger$ & 725 & 390,375 & 425,300 & $425,210,110$ & $550,125,90$ \\
\hline Ga. europaeus DSM $6160^{\mathrm{T}}$ & 725 & 390,375 & 425,300 & $425,210,110$ & $550,125,90$ \\
\hline Ga. diazotrophicus DSM $5601^{\mathrm{T}}$ & 790 & 395,375 & 790 & $435,210,110$ & 650,125 \\
\hline Ac. methanolica $\mathrm{LMG} 1668^{\mathrm{T}}$ & 775 & 410,350 & 700,175 & $400,225,110$ & 440,275 \\
\hline
\end{tabular}

* Reclassified in this study as Acetobacter aceti.

$\dagger$ Reclassified in this study as Gluconacetobacter liquefaciens/Gluconacetobacter xylinus/Gluconacetobacter europaeus.

domly, since all the enzymes tested provided similar information on the reference strains. Six different restriction patterns were obtained with $C f o \mathrm{I}$ and seven with HaeIII. All of these patterns were different from those obtained with the reference strains.

\section{DISCUSSION}

\section{PCR-RFLP of the 16S rDNA}

The methodology used allowed us to differentiate the four genera of acetic acid bacteria as well as to identify natural isolates at the genus level. Also, identification at the species (Gluconobacter oxydans, Acetobacter aceti, Acetobacter pasteurianus, Gluconacetobacter hansenii, Gluconacetobacter diazotrophicus and Acidomonas methanolica) or related species group (Gluconobacter frateurii/Gluconobacter asaii and Gluconacetobacter liquefaciens/Gluconacetobacter xylinus/ Gluconacetobacter europaeus) level was possible. Such identification has traditionally been performed by studying physiological and chemotaxonomic properties (Buchanan \& Gibbons, 1984), but the methods are not completely reliable and are often time-consuming. PCR-RFLP of the 16S rDNA with TaqI and RsaI allows identification of acetic acid bacteria colonies in one working day.

Gluconobacter frateurii and Gluconobacter asaii have been reported as different species on the basis of
DNA-DNA hybridization (Mason \& Claus, 1989) and their species status is supported phenotypically by their differential growth on nicotinate, ribitol and arabitol (Buchanan \& Gibbons, 1984). These features have not been reflected in our 16S rDNA analysis, as they could not be differentiated. In a previous study, Gluconacetobacter liquefaciens, Gluconacetobacter xylinus and Gluconacetobacter europaeus showed a high percentage of similarity between their 16S rDNA sequences (more than $97 \%$; Sievers et al., 1994). A study by Yamada et al. (1997) based on a $156 \mathrm{bp}$ partial sequence of $16 \mathrm{~S}$ rDNA revealed slight nucleotide differences between these species ( $4 \mathrm{bp}$ at most). Obviously, these differences were not detected with the restriction enzymes used in this study.

Some likely classification errors were found. Strain LMG 1511, formerly classified as Gluconacetobacter hansenii, showed the same restriction patterns as the Acetobacter aceti strains. Biochemical tests performed on this strain showed its capacity to grow with ethanol as a sole carbon source, and this feature does not correspond to a strain of Gluconacetobacter hansenii, while growth under these conditions is one of the characteristics of Acetobacter aceti (Buchanan \& Gibbons, 1984). These properties demonstrate that this strain should be classified as Acetobacter aceti. In the same way, strain LMG 1282, formerly classified as Acetobacter pasteurianus, yielded the same pattern as 
Gluconacetobacter liquefaciens/Gluconacetobacter xylinus/Gluconacetobacter europaeus with all of the enzymes tested. Moreover, this strain was positive for ketogenesis from glycerol, which is positive in members of the genus Gluconacetobacter and negative in Acetobacter pasteurianus (Buchanan \& Gibbons, 1984). From these data, strain LMG 1282 should be considered as a member of the genus Gluconacetobacter.

Application of this method to colonies of acetic acid bacteria isolated from wine allowed us to identify them at the species level by using TaqI and RsaI. Biochemical identification tests performed on these strains confirmed the PCR-RFLP results (data not shown). The species found were Gluconobacter oxydans, Acetobacter aceti and Gluconacetobacter hansenii. The presence of these species of acetic acid bacteria in wines has been reported widely (Joyeux et al., 1984; Drysdale \& Fleet, 1985).

\section{PCR-RFLP of the 16S-23S rDNA ITS}

Two to 11 copies of the rRNA loci are present on the chromosomes of most bacterial species and, in some bacterial groups, the different copies of the intergenic spacer regions show extensive length variation (Dolzani et al., 1995; Lagatolla et al., 1996). A minimum of four copies of the rrn locus have been described in Gluconacetobacter xylinus and Gluconacetobacter europaeus, all of them having identical length and sequence (Sievers et al., 1996). In our hands, only one amplified ITS fragment was obtained for each strain, confirming that there is no length variation in the ITS region within each strain of acetic acid bacteria. Moreover, in all the strains studied, the sum of the lengths of the restriction fragments obtained with the eight restriction endonucleases equalled the length of the corresponding PCR-amplified ITS sequence, indicating that all of the ITS copies within each strain have very similar sequences.

Intergenic rDNA sequences are known to have higher variability than functional sequences of the rrn cistrons, allowing the distinction of bacteria below the species level in some cases (Navarro et al., 1992). On this basis, a higher degree of differentiation was expected from PCR-RFLP of the 16S-23S rDNA intergenic spacer than was observed in the $16 \mathrm{~S}$ analysis, even below the species level. Differentiation to the species level was observed for acetic acid bacteria isolated from wine, which yielded neither the same amplified sizes nor the same restriction patterns as the reference strains. These results indicate that the higher variability of the ITS sequence and length in acetic acid bacteria can be used to identify strains or related groups of strains, while it is not extensible to rapid species identification, because of the lack of pattern identity among strains belonging to the same species.

In contrast, in the reference strains, practically the same degree of differentiation was obtained as in the $16 \mathrm{~S}$ analysis. This indicates that the non-distinguished reference strains are very closely related and this could be because these strains have common original substrates or because of the long period spent in the culture collections.

As in the $16 \mathrm{~S}$ experiment, reference strains belonging to the species Gluconacetobacter liquefaciens, Gluconacetobacter xylinus and Gluconacetobacter europaeus could not be distinguished, despite the high sequence and length variability observed in the ITS. This result and the fact that the 16S rRNA genes of these species have a high percentage of homology (up to $97 \%$; Sievers et al., 1994) raises questions about maintaining them as separate species.

Strain Acetobacter pasteurianus LMG 1282 again showed the same patterns as the reference strains belonging to Gluconacetobacter liquefaciens, Gluconacetobacter xylinus and Gluconacetobacter europaeus, confirming the conclusions derived from the $16 \mathrm{~S}$ analysis. However, strain Gluconacetobacter hansenii LMG 1511 did not share the same patterns as the Acetobacter aceti strains, as it did in the $16 \mathrm{~S}$ experiment, representing the only case of variability at the species level within the reference strains.

\section{ACKNOWLEDGEMENTS}

This work was supported financially by the National Research Programs of Food Technology ALI96-0497 and ALI97-1077-CO2-02.

\section{REFERENCES}

Barry, T., Colleran, G., Glennon, M., Dunican, L. K. \& Gannon, F. (1991). The $16 \mathrm{~S} / 23 \mathrm{~S}$ ribosomal spacer region as a target for DNA probes to identify eubacteria, PCR Methods Appl 1, 51-56.

Bej, A. K., Mahbubani, M. H. \& Atlas, R. M. (1991). Amplification of nucleic acids by polymerase chain reaction (PCR) and other methods and their applications, Crit Rev Biochem Mol Biol 26, 301-334.

Boesch, C., Trcek, J., Sievers, M. \& Teuber, M. (1998). Acetobacter intermedius, sp. nov, Syst Appl Microbiol 21, 220-229.

Bulygina, E. S., Gulikova, O. M., Dikanskaya, E. M., Netrusov, A. I., Tourova, T. P. \& Chumakov, K. M. (1992). Taxonomic studies of the genera Acidomonas, Acetobacter and Gluconobacter by $5 \mathrm{~S}$ ribosomal RNA sequencing, J Gen Microbiol 138, 2283-2286.

Carlotti, A. \& Funke, G. (1994). Rapid distinction of Brevibacterium species by restriction analysis of rDNA generated by polymerase chain reaction, Syst Appl Microbiol 17, 380-386.

De Ley, J., Gillis, M. \& Swings, J. (1984). Family VI. Acetobacteraceae. In Bergey's Manual of Systematic Bacteriology, vol. 1, pp. 267-278. Edited by N. R. Krieg \& J. G. Holt. Baltimore: Williams \& Wilkins.

Dolzani, L., Tonin, E., Lagatolla, C., Prandin, L. \& Monti-Bragadin, C. (1995). Identification of Acinetobacter isolates in the $A$. calcoaceticus- $A$. baumannii complex by restriction analysis of the $16 \mathrm{~S}-23 \mathrm{~S}$ rRNA intergenic-spacer sequences, $J$ Clin Microbiol 33, 1108-1113. 
Drysdale, G. S. \& Fleet, G. H. (1985). Acetic acid bacteria in some Australian wines, Food Technol Aust 37, 17-20.

Entani, E., Ohmori, S., Masai, H. \& Suzuki, K.-I. (1985). Acetobacter polyoxogenes sp. nov., a new species of an acetic acid bacterium useful for producing vinegar with high acidity, J Gen Appl Microbiol 31, 475-490.

Franke, I. H., Fegan, M., Hayward, C., Leonard, G., Stackebrandt, E. \& Sly, L. I. (1999). Description of Gluconacetobacter sacchari sp. nov., a new species of acetic acid bacterium isolated from the leaf sheath of sugar cane and from the pink sugar-cane mealy bug, Int J Syst Bacteriol 49, 1681-1693.

Gillis, M. \& De Ley, J. (1980). Intra- and intergeneric similarities of the ribosomal ribonucleic acid cistrons of Acetobacter and Gluconobacter, Int J Syst Bacteriol 30, 7-27.

Gillis, M., Kersters, K., Hoste, B., Janssens, D., Kroppenstedt, R. M., Stephan, M. P., Teixeira, K. R. S., Döbereiner, J. \& De Ley, J. (1989). Acetobacter diazotrophicus sp. nov., a nitrogen-fixing acetic acid bacterium associated with sugarcane, Int $J$ Syst Bacteriol 39, 361-364.

Higgins, D. G. \& Sharp, P. M. (1988). CLUSTAL: a package for performing multiple sequence alignment on a microcomputer, Gene 73, 237-244.

Jensen, M. A., Webster, J. A. \& Straus, N. (1993). Rapid identification of bacteria on the basis of polymerase chain reactionamplified ribosomal DNA spacer polymorphisms, Appl Environ Microbiol 59, 945-952.

Joyeux, A., Lafon-Lafourcade, S. \& Ribéreau-Gayon, P. (1984). Evolution of acetic acid bacteria during fermentation and storage of wine, Appl Environ Microbiol 48, 153-156.

Lagatolla, C., Dolzani, L., Tonin, E., Lavenia, A., Di Michele, M., Tommasini, T. \& Monti-Bragadin, C. (1996). PCR ribotyping for characterizing Salmonella isolates of different serotypes, J Clin Microbiol 34, 2440-2443.

Mason, L. M. \& Claus, W. (1989). Phenotypic characteristics correlated with deoxyribonucleic acid sequence similarities for three species of Gluconobacter: G. oxydans (Henneberg 1897) De Ley 1961, G. frateurii sp. nov., and G. asaii sp. nov, Int J Syst Bacteriol 39, 174-184.
Micales, B. K., Johnson, J. L. \& Claus, G. W. (1985). Deoxyribonucleic acid homologies among organisms in the genus Gluconobacter, Int J Syst Bacteriol 35, 79-85.

Navarro, E., Simonet, P., Normand, P. \& Bardin, R. (1992). Characterisation of natural populations of Nitrobacter spp. using PCR/RFLP analysis of the ribosomal intergenic spacer, Arch Microbiol 157, 107-115.

Sievers, M., Sellmer, S. \& Teuber, M. (1992). Acetobacter europaeus sp. nov., a main component of industrial vinegar fermenters in Central Europe, Syst Appl Microbiol 15, 386-392.

Sievers, M., Ludwig, W. \& Teuber, M. (1994). Phylogenetic positioning of Acetobacter, Gluconobacter, Rhodopila and Acidiphilum species as a branch of acidophilic bacteria in the $\alpha$ subclass of Proteobacteria based on 16S ribosomal DNA sequences, Syst Appl Microbiol 17, 189-196.

Sievers, M., Alonso, L., Gianotti, S., Boesch, C. \& Teuber, M. (1996). 16S-23S ribosomal RNA spacer regions of Acetobacter europaeus and $A$. xylinum, tRNA genes and antitermination sequences, FEMS Microbiol Lett 142, 43-48.

Sokollek, S. J., Hertel, C. \& Hammes, W. P. (1998). Description of Acetobacter oboediens sp. nov. and Acetobacter pomorum sp. nov., two new species isolated from industrial vinegar fermentations, Int J Syst Bacteriol 48, 935-940.

Urakami, T., Tamaoka, J., Suzuki, K. \& Komagata, K. (1989). Acidomonas gen. nov., incorporating Acetobacter methanolicus as Acidomonas methanolica comb. nov, Int J Syst Bacteriol 39, 50-55.

Yamada, Y. \& Kondo, K. (1984). Gluconacetobacter, a new subgenus comprising the acetate-oxidizing acetic acid bacteria with ubiquinone-10 in the genus Acetobacter, J Gen Appl Microbiol 30, 297-303.

Yamada, Y., Itakura, N., Yamashita, M. \& Tahara, Y. (1984). Deoxyribonucleic acid homologies in strains of Gluconobacter species, J Ferment Technol 62, 595-600.

Yamada, Y., Hoshino, K. \& Ishikawa, T. (1997). The phylogeny of acetic acid bacteria based on the partial sequences of $16 \mathrm{~S}$ ribosomal RNA: the elevation of the subgenus Gluconacetobacter to the generic level, Biosci Biotechnol Biochem 61, $1244-1251$. 